\title{
Effect of butyric acid supplementation and whole wheat inclusion on the performance and carcass traits of broilers
}

\author{
A.M. Aghazadeh ${ }^{\#}$ \& M. TahaYazdi \\ Department of Animal Science, Faculty of Agriculture, Urmia University, Iran

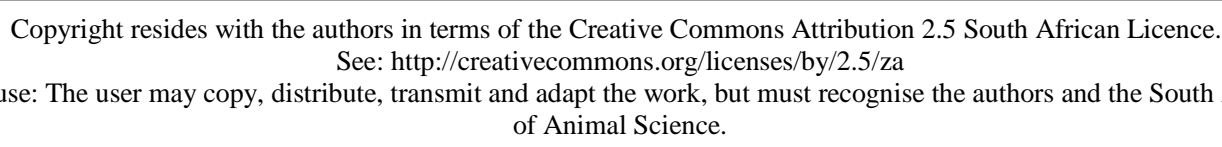

Copyright resides with the authors in terms of the Creative Commons Attribution 2.5 South African Licence. See: http://creativecommons.org/licenses/by/2.5/za of Animal Science. \\ Condition of use: The user may copy, distribute, transmit and adapt the work, but must recognise the authors and the South African Journal
}

\begin{abstract}
To evaluate the effects of butyric acid (BA) levels and wheat form (WF) on the performance of broiler chickens, 320 day-old Ross 308 broiler chicks were randomly distributed among 32 floor pens. A $4 \times 2$ factorial arrangement with four levels of $\mathrm{BA}\left(\mathrm{B}_{1}: 0 \mathrm{~g} \mathrm{BA} / \mathrm{kg}\right.$ in both starter and grower feed; $\mathrm{B}_{2}: 2.5 \mathrm{~g}$ $\mathrm{BA} / \mathrm{kg}$ in both starter and grower feed; $\mathrm{B}_{3}: 2.5 \mathrm{~g} \mathrm{BA} / \mathrm{kg}$ in starter and $1 \mathrm{~g} \mathrm{BA} / \mathrm{kg}$ in grower feed; and $\mathrm{B}_{4}: 2.5$ $\mathrm{g} \mathrm{BA} / \mathrm{kg}$ in starter and $0 \mathrm{~g} \mathrm{BA} / \mathrm{kg}$ in grower feed) and two forms of wheat (whole (WW) vs. ground (GW)) were used. Dietary supplementation with BA had no effect on average weight gain (AWG) or feed conversion ratio (FCR) in the starter, grower/finisher and over whole (0 - $42 \mathrm{~d})$ trial periods. However, birds consumed more when the diet was supplemented with butyrate $\left(B_{2}\right)$ relative to the control and other experimental diets during $0-42 \mathrm{~d}$, but this increase was not associated with improved AWG or FCR as compared with that of the control. The BA had no significant effect on relative fat pad, gizzard or breast meat, but increased liver weight. The length of the entire gut was augmented by BA and WW feeding. Feeding WW increased the relative weight of the gizzard and liver, but decreased the relative weight of abdominal fat. Two-way interactions were not significant for any of the carcass traits or organ-size parameters except for breast meat, in which a significant interaction was observed between BA and WF.
\end{abstract}

Keywords: Broiler, butyrate, gut, performance, whole grain

" Corresponding author: a.aghazadeh@urmia.ac.ir

\section{Introduction}

Health of the gut is one of the major factors governing the performance of birds, and thus the economics of poultry production (Samik et al., 2007). Gut microflora have a significant effect on gut health, host nutrition and growth performance (Barrow, 1992) by interacting nutrient utilization and development of gut system of the host.

In recent years, short-chain fatty acid (SCFA) supplementation of broiler diets, particularly butyric acid (BA), has attracted attention in the commercial poultry industry, a trend that appears to be driven by the need to evaluate an alternative to antibiotics, following the ban on the use of antibiotic growth promoters in animal feeds in the European Union (Dibner \& Richards, 2005). In addition to the antimicrobial abilities of BA, reported beneficial effects include improving the growth of gastrointestinal mucosa (Dibner \& Richards, 2005), providing energy-yielding substrates to the host after absorption (Josefiak et al., 2004) and stimulating intestinal blood flow and the synthesis of gastrointestinal hormones (Mineo et al., 1994).

Previous studies reported that SCFA in general and BA in particular have shown variable effects on the performance of broiler chickens. However, observed effects are either positive (Mahdavi \& Torki, 2009; Taherpour et al., 2009) or positive, but not significant (Lesson et al., 2005; Antongiovani et al., 2007; Hu \& Guo, 2007).

However, the reported BA results were founded mainly on studies based on maize and soybean meal rather than other grains. It is well known that diet composition (Engberg et al., 2004) and feed form (Engberg et al., 2002) appear to have marked effects on intestinal microflora, intestinal health and function. In recent years, whole grain feeding of broilers has attracted attention to lower feed costs. However, other beneficial effects such as improvement in performance, gut health and general flock health (Cummings, 
1994; Forbes \& Covsa, 1995; Wu \& Ravindran, 2004) have been reported. The objective of this study was to determine whether a nutritional BA could affect the performance and carcass traits of birds when fed with two forms of wheat (whole vs. ground).

\section{Material and Methods}

A total of 320 one-day-old male broiler (Ross 308) chicks, obtained from a commercial hatchery and vaccinated against Marek's disease and bronchitis, were randomly assigned to 32 pens with wood shavings on the floor. Each pen was equipped with a tubular feeder and a bell-type waterer. Four replicate pens of 10 birds per pen were allotted to each dietary treatment. A lighting programme was used according to the guidelines of the Ross 308. Room temperature was maintained at $32 \pm 1{ }^{\circ} \mathrm{C}$ during the first week and gradually reduced to $22{ }^{\circ} \mathrm{C}$ by the end of the third week. This temperature was maintained until the end of d 42 of the experiment. The broilers were handled according to the principles of the Urmia Directorate General of Veterinary Services for the care of animals in experimentation.

The experimental design was a completely randomized design with a $4 \times 2$ factorial arrangement of treatments, which included four levels of butyric acid $\left(\mathrm{B}_{1}: 0 \mathrm{~g} \mathrm{BA} / \mathrm{kg}\right.$ in both starter and grower feed; $\mathrm{B}_{2}: 2.5$ $\mathrm{g} \mathrm{BA} / \mathrm{kg}$ in both starter and grower feed; $\mathrm{B}_{3}: 2.5 \mathrm{~g} \mathrm{BA} / \mathrm{kg}$ in starter and $1 \mathrm{~g} \mathrm{BA} / \mathrm{kg}$ in grower feed and $\mathrm{B}_{4}$ : $2.5 \mathrm{~g} \mathrm{BA} / \mathrm{kg}$ in starter and $0 \mathrm{~g} \mathrm{BA} / \mathrm{kg}$ in grower feed) and two forms of locally grown wheat grain (whole vs. ground). The BA was added to the diet by first mixing it with a small proportion of ground grain, which was then mixed with the rest of the diet ingredients. The composition and nutrient analysis of the basal diet are shown in Table 1. Commercial butyric acid (Baby $\mathrm{C}_{4}$ powder, SILO Srl. Industria Zootecnica, Italy) was used according to the manufacturer's instructions. A commercially available local hard wheat variety (Sardari), which had been harvested in the previous year, was purchased from local feed manufacturers.

Broilers were weighed, and feed intake was determined on a pen basis at weekly intervals. Feed intake was adjusted for mortality. At 42 days of age two broilers per pen were randomly selected, weighed, and slaughtered for carcass measurements. Breast, abdominal fat, gizzard, liver and intestine were weighed. Average weight gain (AWG), feed conversion ratio (FCR), internal relative organ weight and carcass yield were determined.

The trial was analysed as a $4 \times 2$ factorial arrangement with levels of BA and form of wheat as main effects. Data were analysed using the general linear model procedure of SAS (2002) software. All percentage data were subjected to arcsin square-root transformations prior to analysis. This transformation did not alter statistical interpretation; therefore data are presented as actual percentages. When the analysis of variance was significant, Duncan's multiple-range test was used to separate the means. Statements of statistical significance are based on $P<0.05$.

\section{Result and Discussion}

The effects of dietary supplementation of BA on AWG, feed intake and FCR are presented in Table 2. No differences were observed during the starter ( 0 to $21 \mathrm{~d}$ ) for bird performance parameters except for body weight gain, which was lower $(P<0.05)$ in the $\mathrm{B}_{4}$ diet than in the $\mathrm{B}_{1}$ and $\mathrm{B}_{2}$ diets. However, weight gain was not affected by BA addition during the grower/finisher period (21 - $42 \mathrm{~d}$ ). Regarding the whole trial period, no differences were noted for AWG or FCR (Table 2), but a significant difference was observed in feed intake (0 - $42 \mathrm{~d}$ ). Total feed intake ( 0 - $42 \mathrm{~d}$ ) was greater in the group fed the $\mathrm{B}_{2}$ diet than in those fed the $\mathrm{B}_{3}$ and $\mathrm{B}_{4}$ diets $(P<0.05)$. However, increase in feed intake did not result in an increase in final body weight gain or improved FCR, as previously noted by Mahdavi \& Torki (2009) and Taherpour et al. (2009). Our results for AWG and FCR agree with those of Leeson et al. (2005) and Hu \& Guo (2007), who reported that diet BA (2 to $4 \mathrm{~g} / \mathrm{kg}$ ) had no effect on AWG or FCR during the period from 0 to 42 days. In the present study, the observed lack of effects of BA on performance may be associated with environmental conditions. Well-nourished healthy chicks do not respond positively to growth promoters when they are housed under clean conditions and at a moderate stocking density (Miller, 1987; Anderson et al., 1999).

In the present study, the form of wheat used, had only a limited effect on bird performance (Table 2). No differences were observed in AWG, feed intake and FCR of birds fed diets with whole or ground wheat $(P>0.05)$. Published data on the effects of WW feeding on the performance of broilers have been contradictory, with several recent reports showing beneficial effects (Preston et al., 2000; Wu et al., 2003; 2004). Other reports (Uddin et al., 1996; Taylor \& Jones, 2001; Bennett et al., 2002), however, failed to 
show any advantage of including whole wheat in broiler diets. The present findings are in accordance with the results of Jones \& Taylor (2001), suggesting that the dietary inclusion of whole grain results in similar production responses, as does the incorporation of ground grain in pellets. Two-way interaction between diet BA and WF was not significant for any of performance parameters. Butyric acid supplementation did not improve AWG or FCR, irrespective of WF used, but increased feed intake $(P<0.05)$.

Table 1 Ingredients and nutrient composition of the basal diet $(\mathrm{g} / \mathrm{kg})$

\begin{tabular}{|c|c|c|}
\hline \multirow[b]{2}{*}{ Item } & \multicolumn{2}{|c|}{ Diet } \\
\hline & Starter (1 - 21 d) & Grower/finisher (21 - 42 d) \\
\hline Wheat & 100 & 300 \\
\hline Maize & 471 & 310 \\
\hline Soybean meal & 328 & 279 \\
\hline Soybean oil & 30 & 40 \\
\hline Meat meal & 40 & 40 \\
\hline Limestone & 10.4 & 8.1 \\
\hline Dicalcium phosphate & 11.8 & 11.2 \\
\hline Salt & 2 & 2 \\
\hline Vitamin-mineral premix ${ }^{*}$ & 5.0 & 5.0 \\
\hline DL-methionine & 1.4 & 2.5 \\
\hline L-lysine.HCl & 0 & 1.9 \\
\hline Total & 1000 & 1000 \\
\hline \multicolumn{3}{|l|}{ Calculated values } \\
\hline Metabolizable energy (MJ/kg) & 12.21 & 13.18 \\
\hline Crude protein & 217 & 200 \\
\hline Calcium & 10 & 9 \\
\hline Average phosphorus & 5 & 4.5 \\
\hline Sodium & 1.6 & 1.6 \\
\hline Lysine & 11.7 & 12.5 \\
\hline Methionine +cystine & 8.2 & 8.8 \\
\hline \multicolumn{3}{|c|}{$\begin{array}{l}\text { *Supplied per kilogram of diet: } 11025 \mathrm{IU} \text { of vitamin } \mathrm{A} ; 3528 \mathrm{IU} \text { of vitamin } \mathrm{D}_{3} ; 33 \mathrm{IU} \text { of vitamin } \\
\mathrm{E} \text {; } 0.91 \mathrm{mg} \text { of vitamin } \mathrm{K} ; 2 \mathrm{mg} \text { of thiamin; } 8 \mathrm{mg} \text { of riboflavin; } 55 \mathrm{mg} \text { of niacin; } 18 \mathrm{mg} \text { of Ca } \\
\text { pantothenate; } 5 \mathrm{mg} \text { of vitamin } \mathrm{B}_{6} ; 0.221 \mathrm{mg} \text { of biotin; } 1 \mathrm{mg} \text { of folic acid; } 478 \mathrm{mg} \text { of choline; } 28 \mu \mathrm{gg} \\
\text { of vitamin } \mathrm{B}_{12} ; 75 \mathrm{mg} \text { of zinc; } 40 \mathrm{mg} \text { of iron; } 64 \mathrm{mg} \text { of manganese; } 10 \mathrm{mg} \text { of copper; } 2 \mathrm{mg} \text { of } \\
\text { iodine; and } 0.3 \mathrm{mg} \text { of selenium. } \\
{ }^{\#} \text { Butyric acid ( } 0.2 \text { or } 0.1 \% \text { as a mixture of mono-, di-, and triglycerides) was added to the basal diet } \\
\text { instead of maize. }\end{array}$} \\
\hline
\end{tabular}

Carcass traits and the relative weights of the organs of the broiler chickens at $42 \mathrm{~d}$ as influenced by BA supplementation and WW feeding are shown in Table 3. Dressing percentage and fat pad content were unaffected by BA supplementation. However, the relative fat pad weight of the birds was decreased ( $P$ $<0.05)$ by feeding whole wheat rather than ground. This result may be associated with the fact that wheat grain contains soluble and gelling fibres such as arabinoxylans that decrease apparent lipid digestibility by reducing the concentration of bile acids in the chime and increase the bacterial activity in the small intestine, which may contribute to malabsorption of lipids (Smith et al., 1998). Similar results have been reported by Amerah et al. (2008). In contrast, other researchers have reported higher relative abdominal fat weight when WW was included (Jones \& Taylor, 2001; Nahas \& Lefrancois, 2001). 
Table 2 Effect of different levels of butyric acid and wheat forms on performance of broiler chickens (g/bird)

\begin{tabular}{|c|c|c|c|c|c|c|c|c|c|}
\hline & \multicolumn{3}{|c|}{ Average weight gain } & \multicolumn{3}{|c|}{ Feed intake } & \multicolumn{3}{|c|}{ Feed conversion ratio } \\
\hline & $0-21 d$ & $21-42 d$ & $0-42 d$ & $0-21 d$ & $21-42 d$ & $0-42 \mathrm{~d}$ & $0-21 d$ & $21-42 d$ & $0-42 d$ \\
\hline \multicolumn{10}{|l|}{ Butyric acid (BA) } \\
\hline$B_{1}(0+0 g / k g)^{1}$ & $437^{\mathrm{a}}$ & 1693 & 2130 & 723 & 3058 & $3781^{\mathrm{ab}}$ & 1.66 & 1.80 & 1.77 \\
\hline$B_{2}(2.5+2.5 \mathrm{~g} / \mathrm{kg})$ & $440^{\mathrm{a}}$ & 1703 & 2143 & 728 & 3113 & $3841^{\mathrm{a}}$ & 1.65 & 1.82 & 1.79 \\
\hline $\mathrm{B}_{3}(2.5+1 \mathrm{~g} / \mathrm{kg})$ & $405^{\mathrm{ab}}$ & 1629 & 2035 & 690 & 2950 & $3640^{\mathrm{b}}$ & 1.70 & 1.81 & 1.79 \\
\hline $\mathrm{B}_{4}(2.5+0 \mathrm{~g} / \mathrm{kg})$ & 396. ${ }^{\mathrm{b}}$ & 1655 & 2051 & 691 & 2954 & $3646^{\mathrm{b}}$ & 1.74 & 1.78 & 1.78 \\
\hline$\pm \operatorname{SEM}(n=8)$ & 12.0 & 34.0 & 38.3 & 14.7 & 51.2 & 54.7 & 0.03 & 0.02 & 0.01 \\
\hline \multicolumn{10}{|l|}{ Wheat form (WF) } \\
\hline Whole (W) & 414 & 1638 & 2051 & 703 & 2980 & 3682 & 1.70 & 1.82 & 1.79 \\
\hline Ground (G) & 426 & 1702 & 2128 & 713 & 3058 & 3771 & 1.68 & 1.79 & 1.77 \\
\hline$\pm \operatorname{SEM}(n=16)$ & 8.5 & 24.0 & 27.0 & 10.4 & 36.2 & 38.7 & 0.02 & 0.01 & 0.01 \\
\hline \multicolumn{10}{|l|}{ Butyric acid $\times$ wheat form } \\
\hline $\mathrm{A}\left(\mathrm{W} \times \mathrm{B}_{1}\right)$ & 430 & 1640 & 2070 & 717 & 2977 & 3696 & 1.67 & 1.81 & 1.78 \\
\hline $\mathrm{B}\left(\mathrm{W} \times \mathrm{B}_{2}\right)$ & 435 & 1663 & 2098 & 705 & 3049 & 3755 & 1.62 & 1.83 & 1.79 \\
\hline $\mathrm{C}\left(\mathrm{W} \times \mathrm{B}_{3}\right)$ & 402 & 1616 & 2018 & 702 & 2968 & 3671 & 1.75 & 1.83 & 1.82 \\
\hline $\mathrm{D}\left(\mathrm{W} \times \mathrm{B}_{4}\right)$ & 388 & 1632 & 2020 & 685 & 2923 & 3607 & 1.77 & 1.79 & 1.79 \\
\hline$E\left(G \times B_{1}\right)$ & 445 & 1746 & 2190 & 730 & 3136 & 3866 & 1.64 & 1.79 & 1.76 \\
\hline$F\left(G \times B_{2}\right)$ & 444 & 1744 & 2188 & 749 & 2177 & 3927 & 1.69 & 1.82 & 1.80 \\
\hline $\mathrm{G}\left(\mathrm{G} \times \mathrm{B}_{3}\right)$ & 409 & 1643 & 2051 & 677 & 2932 & 3609 & 1.65 & 1.79 & 1.76 \\
\hline $\mathrm{H}\left(\mathrm{G} \times \mathrm{B}_{4}\right)$ & 404 & 1677 & 2082 & 697 & 2986 & 3684 & 1.72 & 1.78 & 1.77 \\
\hline \pm SEM $(n=4)$ & 16.9 & 48.1 & 54.1 & 20.8 & 72.5 & 77.4 & 0.05 & 0.02 & 0.02 \\
\hline \multicolumn{10}{|l|}{$P$ value } \\
\hline Butyric acid & 0.0322 & NS & NS & NS & $*$ & 0.0360 & NS & NS & NS \\
\hline Wheat form & NS & $*$ & $*$ & NS & NS & NS & NS & NS & NS \\
\hline $\mathrm{BA} \times \mathrm{WF}$ & NS & NS & NS & NS & NS & NS & NS & NS & NS \\
\hline
\end{tabular}

${ }^{1}$ First and second number in parentheses is relating to concentration of butyric acid in starter and grower/finisher periods, respectively.

a, b, c Column means with different superscripts differ significantly at $P<0.05$.

$* P<0.1$, NS - non-significant. 
Table 3 Effect of butyric acid supplementation and whole wheat feeding on the carcass traits and relative weight of organs and intestine of broiler chickens

\begin{tabular}{|c|c|c|c|c|c|c|c|}
\hline & DP $42 \mathrm{~d}$ & Fat pad $42 \mathrm{~d}$ & Gizzard 42 d & Liver 42 d & Intestine $42 \mathrm{~d}$ & \multirow{2}{*}{$\begin{array}{c}\text { Breast } 42 \text { d } \\
\text { (g/g DP) }\end{array}$} & \multirow{2}{*}{$\begin{array}{l}\mathrm{RIL}^{3} \\
42 \mathrm{~d}\end{array}$} \\
\hline & \multicolumn{5}{|c|}{ (g/g body weight)×100 } & & \\
\hline \multicolumn{8}{|l|}{ Butyric acid (BA) } \\
\hline $\mathrm{B}_{1}(0+0 \mathrm{~g} / \mathrm{kg})^{1}$ & 73.0 & 1.73 & 1.65 & $2.12^{\mathrm{b}}$ & $3.36^{\mathrm{b}}$ & 33.7 & $8.20^{\mathrm{C}}$ \\
\hline $\mathrm{B}_{2}(2.5+2.5 \mathrm{~g} / \mathrm{kg})$ & 70.5 & 1.80 & 1.60 & $2.35^{\mathrm{a}}$ & $3.96^{\mathrm{a}}$ & 33.6 & $8.91^{\mathrm{b}}$ \\
\hline $\mathrm{B}_{3}(2.5+1 \mathrm{~g} / \mathrm{kg})$ & 72.5 & 1.76 & 1.60 & $2.35^{\mathrm{a}}$ & $3.64^{\mathrm{ab}}$ & 34.1 & $8.50^{\mathrm{bc}}$ \\
\hline $\mathrm{B}_{4}(2.5+0 \mathrm{~g} / \mathrm{kg})$ & 71.4 & 1.86 & 1.66 & $2.53^{\mathrm{a}}$ & $3.93^{\mathrm{a}}$ & 34.5 & $9.55^{\mathrm{a}}$ \\
\hline$\pm \operatorname{SEM}(\mathrm{n}=16)$ & 1.0 & 0.13 & 0.06 & 0.06 & 0.15 & 0.49 & 0.20 \\
\hline \multicolumn{8}{|l|}{ Wheat form (WF) } \\
\hline Whole (W) & 71.9 & $1.61^{b}$ & $1.69^{a}$ & $2.43^{\mathrm{a}}$ & 3.85 & 34.0 & $9.11^{\mathrm{a}}$ \\
\hline Ground (G) & 71.9 & $1.96^{a}$ & $1.57^{b}$ & $2.24^{\mathrm{b}}$ & 3.59 & 33.9 & $8.46^{\mathrm{b}}$ \\
\hline$\pm \operatorname{SEM}(n=32)$ & 0.7 & 0.09 & 0.04 & 0.04 & 0.10 & 0.35 & 0.14 \\
\hline \multicolumn{8}{|l|}{ Butyric acid $\times$ wheat form } \\
\hline $\mathrm{A}\left(\mathrm{W} \times \mathrm{B}_{1}\right)$ & 73.5 & 1.54 & 1.67 & 2.13 & 3.31 & $33.3^{\mathrm{bcd}}$ & 8.15 \\
\hline $\mathrm{B}\left(\mathrm{W} \times \mathrm{B}_{2}\right)$ & 71.0 & 1.47 & 1.68 & 2.44 & 4.24 & $32.5^{\mathrm{d}}$ & 9.53 \\
\hline $\mathrm{C}\left(\mathrm{W} \times \mathrm{B}_{3}\right)$ & 72.2 & 1.68 & 1.70 & 2.41 & 3.71 & $35.3^{a}$ & 8.73 \\
\hline $\mathrm{D}\left(\mathrm{W} \times \mathrm{B}_{4}\right)$ & 70.9 & 1.77 & 1.69 & 2.76 & 4.12 & $35.0^{\mathrm{ab}}$ & 10.05 \\
\hline$E\left(G \times B_{1}\right)$ & 72.5 & 1.92 & 1.63 & 2.12 & 3.40 & $34.2^{\mathrm{abcd}}$ & 8.25 \\
\hline$F\left(G \times B_{2}\right)$ & 73.1 & 2.14 & 1.52 & 2.26 & 3.67 & $34.7^{\mathrm{abc}}$ & 8.29 \\
\hline $\mathrm{G}\left(\mathrm{G} \times \mathrm{B}_{3}\right)$ & 72.8 & 1.84 & 1.51 & 2.28 & 3.56 & $32.9^{\text {cd }}$ & 8.27 \\
\hline $\mathrm{H}\left(\mathrm{G} \times \mathrm{B}_{4}\right)$ & 72.0 & 1.94 & 1.62 & 2.30 & 3.74 & $34.0^{\mathrm{abcd}}$ & 9.05 \\
\hline$\pm \operatorname{SEM}(n=8)$ & 1.5 & 0.18 & 0.08 & 0.09 & 0.21 & 0.69 & 0.29 \\
\hline \multicolumn{8}{|l|}{$P$ value } \\
\hline Butyric acid & NS & NS & NS & 0.014 & 0.0171 & NS & 0.0001 \\
\hline Wheat form & NS & 0.0089 & 0.0414 & 0.0057 & NS & NS & 0.0024 \\
\hline $\mathrm{BA} \times \mathrm{WF}$ & NS & NS & NS & NS & NS & 0.0078 & NS \\
\hline
\end{tabular}

${ }^{1}$ First and second number in parentheses is relating to concentration of butyric acid in starter and grower/finisher periods respectively. ${ }^{2} \mathrm{DP}$ - dressing percentage; ${ }^{3} \mathrm{RIL}$ - relative intestinal length $(\mathrm{cm} / \mathrm{g}$ body weight $\times 100)$.

a, b, c Column means with different superscripts differ significantly at $P<0.05$; ${ }^{*} P<0.1$, NS - non-significant. 
Butyric acid supplementation had no effects $(P>0.05)$ on breast meat in WF, but an improvement in $\mathrm{C}$ $\left(\mathrm{W} \times \mathrm{B}_{3}\right)$ diet was higher than the control, $\mathrm{B}_{2}$ and $\mathrm{B}_{4}$ diets, as indicated by a significant interaction between WW and BA diets. These results are in contrast to those of Leeson et al. (2005) and Antongiovanni et al. (2007), who reported that breast meat yield was unaffected by treatment.

With WW, we observed a higher relative gizzard weight than with GW diets. Greater weight of the gizzard was previously observed with whole grain compared with pelleted ground diet (Cumming, 1994; Forbes \& Covasa, 1995; Preston et al., 2000). The greater development is owing to increased frequency of gizzard contractions (Hill, 1971; Roche, 1981) to cope with the extra grinding needed to process the larger particle size for further digestion in the distal parts of the intestine.

Liver weight was affected by BA addition and WW feeding $(P<0.05)$. The liver is a site of detoxification and bile production, thus it is suggested that liver size is dependent on the amount of work it does. Brenes et al. (1993) stated that after absorption, the liver is the major site of SCFA metabolism, where propionic and butyric acids are almost entirely taken up. Thus, they suggested that liver size is dependent on the gastrointestinal microflora and/or their fermentation products. Results from experiments indicate that the improved feed value sometimes observed with WW may be associated with modulation of digestive processes resulting in increased pancreas and liver secretions (Svihus et al., 2004).

In the present study no interaction was observed for relative liver weight and intestinal length at 42 days of age $(P>0.05)$. These results show that the use of supplemental BA in maize-wheat-based diets for broilers is beneficial, irrespective of the presentation method of the wheat. It is plausible that this result is a consequence of increased grinding activity of the larger gizzard and enhanced mixing of the substrate with the supplemental BA. Published data on the interaction between BA supplementation and WF are limited, and further studies on this subject may be warranted.

The weight of the entire gut was increased by supplemental BA and WW feeding $(P<0.05)$. These results are similar to those of Steenfeldt (2001) and Svihus \& Hetland (2001), but different from those of Svihus et al. (1997) and Jones \& Taylor (2001) who found no differences in the weight or length of the intestinal tract using sorghum-based diets containing $200 \mathrm{~g} \mathrm{WW} / \mathrm{kg}$ feed. These conflicting results may be because of differences in methodology and experimental protocols (Taylor \& Jones, 2001) or in the dietary nutrient density in the basal diets (Jones \& Taylor, 2001) and differences in wheat cultivars (Steenfeldt, 2001).

\section{Conclusions}

Broiler chickens fed on diets containing up to $2.5 \mathrm{~g} \mathrm{BA} / \mathrm{kg}$ to $\mathrm{d} 21$ only, irrespective of the cereal or cereal form used, showed similar AWG, FCR and carcass yield to those fed BA-free diets. Relative liver and intestinal weights were heavier, and intestinal length was greater in BA-supplemented broilers than in the control-fed diet. These results may encourage poultry producers to include their own locally grown whole grains in broiler diets supplemented with BA. That, in turn, could reduce feed costs without negatively affecting meat output.

\section{Acknowledgment}

The authors are grateful to Sana Dam Pars Co. and SILO Srl. for help with providing butyric acid glycerides $\left(\mathrm{C}_{4}\right.$ powder$)$ and for partly funding this work.

\section{References}

Amerah, A.M., Ravindran, V., Lentle, R.G. \& Thomas, D.G., 2008. Influence of feed particle size on the performance, energy utilization, digestive tract development, and digesta parameters of broiler starters fed wheat- and corn-based diets. Poult. Sci. 87, 2320-2328.

Anderson, D.B., McCracken, V.J., Aminov, R.I., Simpson, J.M., Mackie, R.I., Vestegen, M.W.A. \& Gaskins, H.R., 1999. Gut microbiology and growth-promoting antibiotics in swine. Pig News Info. 20, $115 \mathrm{~N}-122 \mathrm{~N}$.

Antongiovanni, M., Buccioni, A., Petacchi, F., Leeson, S., Miineri, S., Martiin, A. \& Cecchi, R., 2007. Butyric acid glycerides in the diet of broiler chickens: Effects on gut histology and carcass composition. Italian J. Anim. Sci. 6, 19-25.

Barrow, P.A., 1992. Probiotics for chickens. In: Probiotics. Ed. Fuller, R., Chapman and Hall, London. pp. 224-257. 
Bennett, C.D., Classen, H.L. \& Riddell, C., 2002. Feeding broiler chickens wheat and barley diets containing whole, ground and pelleted grain. Poult. Sci. 81, 995-1003.

Brenes, A., Smith, M., Guenter, W. \& Marquardt, R.R., 1993.Effect of enzyme supplementation on the performance and digestive tract size of broiler chickens fed wheat- and barley-based diets. Poult. Sci. 72, 1731-1739.

Cummings, R.B., 1994. Opportunities for whole grain feeding. In: Proc. Ninth European Poultry Conference, Glasgow, UK. pp. 219-222.

Dibner, J.J. \& Richards, J.D., 2005. Antibiotic growth promoters in agriculture: History and mode of action. Poult. Sci. 84, 634-643.

Engberg, R.M., Hedemann, M.S., Steenfeldt, S. \& Jensen, B.B., 2004. Influence of whole wheat and xylanase on broiler performance and microbial composition and activity in the digestive tract. Poult. Sci. 83, 925-938.

Engberg, R.M., Hedemarm, M.S. \& Jensen, B.B., 2002. The influence of grinding and pelleting of feed on the microbial composition and activity in the digestive tract of broiler chickens. Br. Poult. Sci. 44, 569-579.

Forbes, J.M. \& Covasa, M., 1995. Application of diet selection by poultry with particular reference to whole cereals. Wrld's Poult. Sci. J. 51, 149-165.

Hill, K.J., 1971. The Physiology of Digestion. In: Physiology and Biochemistry of the Domestic Fowl. Eds Bell, D.J. \& Freeman, B.M., Academic Press, London. pp. 25-49.

Hu, Z. \& Guo, Y., 2007. Effects of dietary sodium butyrate supplementation on the intestinal morphological structure, absorptive function and gut flora in chickens. Anim. Feed Sci. Technol. 132, 240-249.

Jones, G.P.D. \& Taylor, R.D., 2001. The incorporation of whole grain into pelleted broiler chicken diets: production and physiological responses. Br. Poult. Sci. 42, 477-483.

Jósefiak, D., Rutkowski, A. \& Martin, S.A., 2004. Carbohydrate fermentation in the avian ceca: A review. Anim. Feed Sci. Technol. 113, 1-15.

Leeson, S., Namkung, H., Antongiovanni, M. \& Lee, E.H., 2005. Effect of butyric acid on the performance and carcass yield of broiler chickens. Poult. Sci. 84, 1418-1422.

Mahdavi, R. \& Toki, M., 2009. Study on usage period of dietary protected butyric acid on performance, carcass characteristics, serum metabolite levels and humoral immune response of broiler chickens. J. Anim. Vet. Adv. 8 (9), 1702-1709.

Miller, B.F., 1987. Acidified poultry diets and their implications for the poultry Industry. In: Biotechnology in the Feed Industry. Ed. Lyons, T.P., Alltech. Technical Publication. Kentucky. pp. 199-209.

Mineo, H., Hashizume, Y., Hanaki, Y., Murata, K., Maeda, H., Onaga, T., Kato, S. \& Yanaihara, N., 1994. Chemical specificity of short-chain fatty acids in stimulating insulin and glucagons secretion in sheep. Am. J. Physiol. 267, 234-241.

Nahas, J. \& Lefrancois, M.R., 2001. Effects of feeding locally grown whole barley with or without enzyme addition and whole wheat on broiler performance and carcass traits. Poult. Sci. 80, 195-202.

Preston, C.M., McCracken, K.J. \& McAllister, A., 2000. Effect of diet form and enzyme supplementation on growth, efficiency and energy utilisation of wheat-based diets for broilers. Br. Poult. Sci. 41, 324-331.

Roche, M., 1981. Feeding behaviour and digestive motility of birds. Reproduction, Nutrition, Development 21, 781-788.

Samik, K.P., Halder, G., Mondel, M.K. \& Samanta, G., 2007. Effect of organic acid salt on the performance and gut health of broiler chicken. J. Poult. Sci. 44, 389-395.

SAS, 2002. Statistical Analysis Systems user's guide. (9.0) SAS Institute Inc., Raleigh, North Carolina, USA.

Smits, C.H.M., Veldman, A., Verkade, H.J. \& Beynen, A.C., 1998. The inhibitory effect of carboxymethylcellulose with high viscosity on lipid absorption in broiler chickens coincides with reduced bile salt concentration and raised microbial numbers in the small intestine. Poult. Sci. 77, 1534-1539.

Steenfeldt, S., 2001. The dietary effect of different wheat cultivars for broiler chickens. Br. Poult. Sci. 42, 595-609.

Svihus, B. \& Hetland, H., 2001. Ileal starch digestibility in growing broiler chickens fed on a wheat-based diet is improved by mash feeding, dilution with cellulose or whole wheat inclusion. Br. Poult. Sci. 42, 633-637. 
Svihus, B., Herstad, O., Newman, C.W. \& Newman, R.K., 1997. Comparison of performance and intestinal characteristics of broiler chickens fed on diets containing whole, rolled or ground barley. Br. Poult. Sci. 38, 524-529.

Svihus, B., Juvik, E., Hetland, H. \& Krogdahl, A., 2004. Causes for improvement in nutritive value of broiler chicken diets with whole wheat instead of ground wheat. Br. Poult. Sci. 45, 55-60.

Taherpour, K., Moravej, H., Shivazad, M., Adibmoradi, M. \& Yakhchali, B., 2009. Effect of dietary probiotic, prebiotic and butyric acid glycerides on performance and serum composition in broiler chickens. Afr. J. Biotechnol. 8 (10), 2329-2334.

Taylor, R.D. \& Jones, G.P.D., 2001. The effect of whole wheat, ground wheat and dietary enzymes on performance and gastro-intestinal morphology of broilers. Proc. Aust. Poult. Sci. Symp. 13, 187-190.

Uddin, M.S., Rose, S.P., Hiscock, T.A. \& Bonnet, S., 1996. A comparison of the energy availability for chickens of ground and whole grain samples of two wheat varieties. Br. Poult. Sci. 37, 347-357.

Wu, Y.B., Ravindran, V. \& Hendriks, W.H., 2003. Influence of xylanase supplementation and whole wheat inclusion on the performance and gizzard weights in broilers. Proc. Aust. Poult. Sci. Symposium. 15, 103.

Wu, Y.B. \& Ravindran, V., 2004. Influence of whole wheat inclusion and xylanase supplementation on performance, digestive tract measurements and carcass characteristics of broiler chickens. Anim. Feed Sci. Technol. 116, 129-139. 